\title{
P-ISSN 0126-1754
}

E-ISSN 2337-8751

Terakreditasi Peringkat 2

21/E/KPT/2018

LIPI

Berita

Biologi

Jurnal IImu-ilmu Hayati
Volume 19 Nomor 3B, Desember 2020

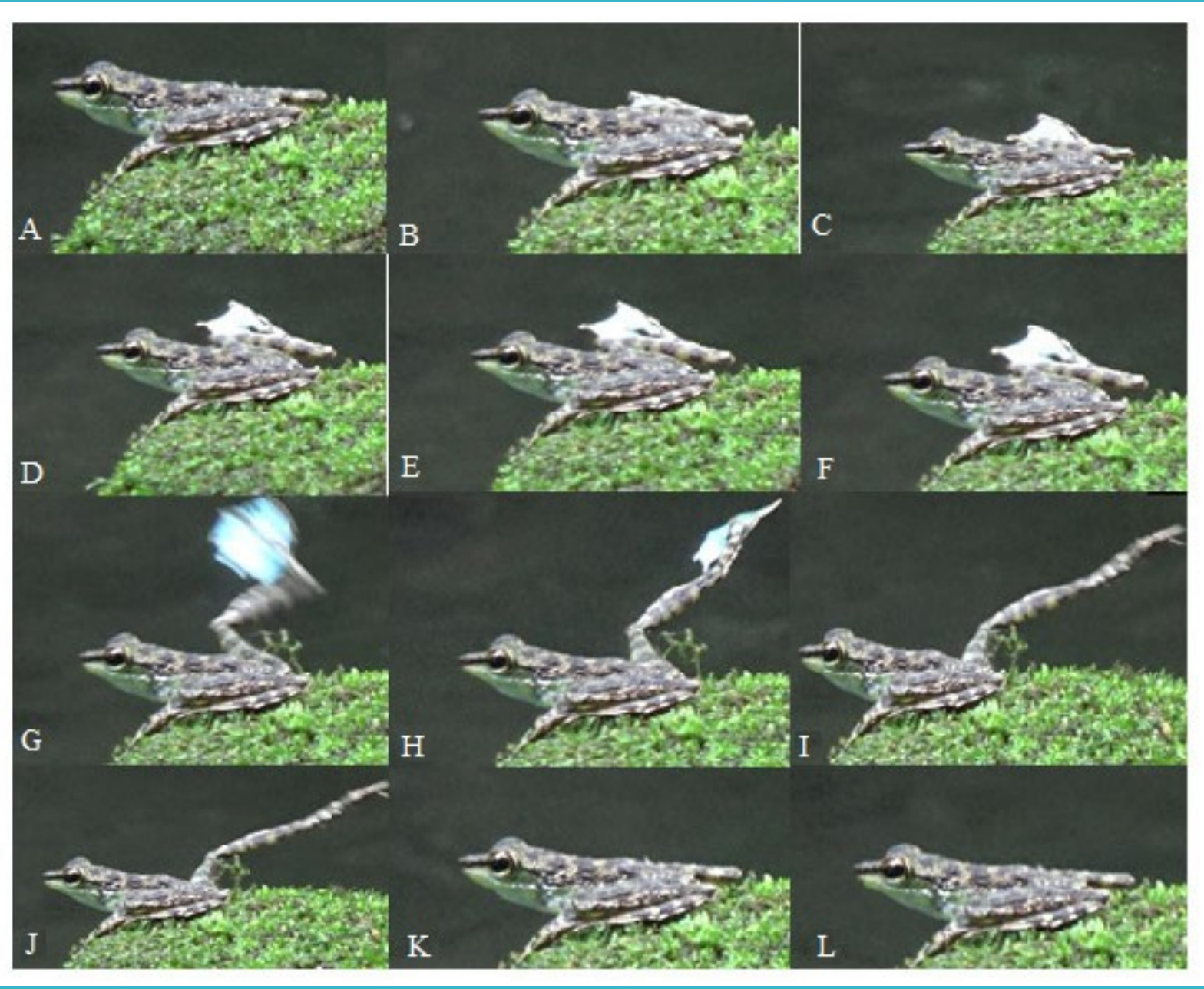

\begin{tabular}{|l|l|l|l|l|l|}
\hline Berita Biologi & Vol. 19 & No. 3B & Hlm. 361-489 & Bogor, Desember 2020 & ISSN 0126-1754 \\
\hline
\end{tabular}

Pusat Penelitian Biologi - LIPI 


\title{
BERITA BIOLOGI
}

Vol. 19 No. 3B Desember 2020

Terakreditasi Berdasarkan Keputusan Direktur Jendral Penguatan Riset dan Pengembangan, Kemenristekdikti RI No. 21/E/KPT/2018

Tim Redaksi (Editorial Team)

Andria Agusta (Pemimpin Redaksi, Editor in Chief)

(Kimia Bahan Alam, Pusat Penelitian Kimia - LIPI)

Kusumadewi Sri Yulita (Redaksi Pelaksana, Managing Editor)

(Sistematika Molekuler Tumbuhan, Pusat Penelitian Biologi - LIPI)

Gono Semiadi

(Mammalogi, Pusat Penelitian Biologi - LIPI)

Atit Kanti

(Mikrobiologi, Pusat Penelitian Biologi - LIPI)

Siti Sundari

(Ekologi Lingkungan, Pusat Penelitian Biologi - LIPI)

Arif Nurkanto

(Mikrobiologi, Pusat Penelitian Biologi - LIPI)

Kartika Dewi

(Taksonomi Nematoda, Pusat Penelitian Biologi - LIPI)

Dwi Setyo Rini

(Biologi Molekuler Tumbuhan, Pusat Penelitian Biologi - LIPI)

\section{Desain dan Layout (Design and Layout)}

Liana Astuti

\section{Kesekretariatan (Secretary) \\ Nira Ariasari, Budiarjo}

\author{
Alamat (Address) \\ Pusat Penelitian Biologi-LIPI \\ Kompleks Cibinong Science Center (CSC-LIPI) \\ Jalan Raya Jakarta-Bogor KM 46, \\ Cibinong 16911, Bogor-Indonesia \\ Telepon (021) 8765066 - 8765067 \\ Faksimili (021) 8765059 \\ Email: berita.biologi@mail.lipi.go.id \\ jurnalberitabiologi@yahoo.co.id \\ jurnalberitabiologi@gmail.com
}

\footnotetext{
Keterangan foto cover depan: Sequence gerakan yang ditunjukan selama foot-flagging pada katak jantan (S. gutattus); (A) saat istirahat; (B) angkat kaki; (C-F) ekstensi kaki parsial; (G-J) ekstensi kaki penuh; (K-L) istirahat, sesuai dengan halaman 385

(Notes of cover picture): $\quad$ (Sequence of movements shown during foot-flagging in male frogs (S. gutattus); (A) at rest; (B) leg lift; (C-F) partial leg extension; (G-J) full leg extension; (K-L) rest), as in page 385)
} 
P-ISSN 0126-1754

E-ISSN 2337-8751

Terakreditasi Peringkat 2

21/E/KPT/2018

Volume 19 Nomor 3B, Desember 2020

LIPI

Berita

Biologi

Jurnal Ilmu-ilmu Hayati 


\section{Ucapan terima kasih kepada \\ Mitra Bebestari nomor ini \\ 19(3B) - Desember 2020}

Dr. Satya Nugroho

(Biologi Molekuler/Rekayasa Genetika Tanaman, Pusat Penelitian Bioteknologi - LIPI)

Dr. Surono, S.P., M.Agr.

(Microbial Ecology/Dark septate endophytic fungi, Balai Penelitian Tanah - Badan Litbang Pertanian)

Dr. Mirza Dikari Kusrini, M.Si.

(Herpetologi, Ekologi Satwaliar, Fakultas Kehutanan, Institut Pertanian Bogor)

Prof. Dr. Dewi Malia Prawiradilaga

(Ekologi Burung, Pusat Penelitian Biologi - LIPI)

Mohammad Irham M.Sc.

(Ekologi \& Taksonomi Burung, Pusat Penelitian Biologi - LIPI)

Dr. Adi Santoso

(Bioteknologi, Pusat Penelitian Bioteknologi - LIPI)

Ir. Endang Purwaningsih

(Taksonomi Nematode pada vertebrata liar, Pusat Penelitian Biologi - LIPI)

Gloria Animalesto S.Si.

(Taksonomi Trematoda pada vertebrata liar, Pusat Penelitian Biologi - LIPI)

Arif Nurkanto, M.Si.

(Mikrobiologi, Pusat Penelitian Biologi - LIPI)

Dr. Bambang Sunarko

(Mikrobiologi, Pusat Penelitian Biologi - LIPI)

Dr.rer.nat.Dwi Setyo Rini M.Si.

(Biologi Molekuler Tumbuhan, Pusat Penelitian Biologi - LIPI)

Dr. Novik Nurhidayat

(Mikrobiologi, Pusat Penelitian Biologi - LIPI)

Dr. Achmad Dinoto M.Sc.

(Mikrobiologi, Pusat Penelitian Biologi - LIPI)

Prof. Dr. Mulyadi

(Biosistematika Copepoda, Pusat Penelitian Biologi - LIPI)

Dr. Conni Margaretha Sidabalok M. App. Sc.

(Biosistematika Isopoda, Pusat Penelitian Biologi - LIPI) 



\title{
EFEK SELENIUM OKSIKLORIDA TERHADAP
} AKTIVITAS IMUNOMODULATOR DARI EKSOPOLISAKARIDA Lactobacillus plantarum [Effect of Selenium Chloride on Immunomodulatory Activity of Exopolysaccharide by Lactobacillus plantarum]

\author{
Fifi Afiati ${ }^{1 *}$, D.C. Agustina $^{2}$, S. Wiryowidagdo ${ }^{2,}$ Kusmiati $^{{ }^{*} \bowtie}$, dan Atit Kanti ${ }^{3}$ \\ 1) Pusat Penelitian Bioteknologi-LIPI, Jl. Raya Jakarta Bogor Km 46, Cibinong 16911 \\ 2) Fakultas Farmasi - Universitas Pancasila, Srengseng Sawah Jagakarsa, Jakarta 12640 \\ 3) InaCC Pusat Penelitian Biologi-LIPI, Jl. Raya Jakarta Bogor Km 46, Cibinong 16911 \\ email:kusmiati02@yahoo.com
}

\section{ABSTRACT}

Lactobacillus plantarum (LAB) is a group of lactic acid bacteria that can produce exopolysaccharide (EPS). The objective of this study was to determine the effect of adding selenium chloride oxide ( $\mathrm{SeOCl} 2)$ to the increased immunomodulatory potential of EPS L. plantarum $Y$-1.2. The experiment was conducted in vivo using macrophage cells of peritoneal fluid of mice induced by Staphylococcus aureus. EPS was obtained by precipitation at $4{ }^{\circ} \mathrm{C}$. Identification test using HPLC showed that crude EPS of L. plantarum Y-1.2 containing glucose monomers for value retention times 4.198 and 4.204, crude EPS approaches the retention time of glucose BP 4.234. Testing of immunomodulatory divided into six treatment groups. Group 1-3 as the control group, a positive control (Stimuno), negative control (crude EPS 50 $\mathrm{mg} / \mathrm{kg} \mathrm{BW}$ in mice), normal control (distilled water). Group 4-6 as the test group was given $\mathrm{crude}$ EPS $50 \mathrm{mg} / \mathrm{kg} \mathrm{BW}$ in mice and selenium oxide chloride doses of $0.13 \mu \mathrm{g} ; 0.26 \mu \mathrm{g} ; 0.52 \mu \mathrm{g}$. The test results showed a dosage of $0.52 \mu \mathrm{g}$ selenium chloride oxide to crude EPS of 50 $\mathrm{mg} / \mathrm{kg} \mathrm{BW}$ in mice could increase the activity and phagocytic capacity amounted to $28.06 \%$ and $28.39 \%$

Keywords: Lactobacillus plantarum, macrophage cells, phagocytic, selenium chloride oxide

\section{ABSTRAK}

Lactobacillus plantarum merupakan kelompok bakteri asam laktat (BAL) yang mampu menghasilkan eksopolisakarida (EPS). Penelitian bertujuan mempelajari efek penambahan selenium klorid oksid (SeOCl2) terhadap peningkatan potensi imunomodulator dari EPS $L$. plantarum Y-1.2. Pengujian secara in vivo menggunakan sel makrofag cairan peritoneum mencit yang diinduksi dengan Staphylococcus aureus. EPS diperoleh dengan cara pengendapan pada suhu $4{ }^{\circ} \mathrm{C}$. Analisis menggunakan KCKT menunjukkan bahwa crude EPS dari $L$. plantarum Y-1.2 mengandung monomer glukosa karena memiliki waktu retensi 4.198 dan 4.204 menit mendekati waktu retensi standar glukosa 4.234 menit. Pengujian imunomodulator dibagi menjadi enam kelompok perlakuan dengan empat ulangan. Kelompok 1-3 merupakan kelompok kontrol yaitu, kontrol positif (Stimuno), kontrol negatif (crude EPS $50 \mathrm{mg} / \mathrm{kg}$ BB mencit), kontrol normal (akuades). Kelompok 4-6 merupakan kelompok uji yang diberikan crude EPS $50 \mathrm{mg} / \mathrm{kg}$ BB mencit dan Selenium Oksiklorida dosis $0,13 \mu \mathrm{g} ; 0,26 \mu \mathrm{g}$; $0,52 \mu \mathrm{g}$ per mencit. Hasil pengujian menunjukkan pemberian Selenium Oksiklorida $0,52 \mu \mathrm{g}$ terhadap crude EPS $50 \mathrm{mg} / \mathrm{kg}$ BB mencit dapat meningkatkan aktivitas dan kapasitas fagositosis sebesar $28,06 \%$ dan $28,39 \%$.

Kata kunci: eksopolisakarida, fagositosis, Lactobacillus plantarum, sel makrofag, Selenium Oksiklorida

\section{PENDAHULUAN}

Sistem imunitas pada manusia merupakan gabungan sel, molekul dan jaringan yang berperan untuk pertahanan tubuh terhadap infeksi. Gangguan yang terjadi pada sistem imunitas manusia akan menyebabkan tubuh berkoordinasi untuk menghasilkan suatu respon imun untuk mempertahankan kekebalan tubuh. Fungsi sistem imunitas manusia yang terganggu akibat pengaruh unsur patogen dapat diperbaiki dengan memberikan senyawa yang bersifat imunomodulator sehingga dapat mengembalikan ketidakseimbangan sistem imun (Bratawidjaja, 2004). Imunomodulator merupakan zat yang dapat merangsang dan memiliki kemampuan untuk mempertahankan sistem pertahanan tubuh bila terganggu, dan menekannya bila berlebih. Selain itu memiliki efek yang dapat meningkatkan aktivitas dan kapasitas fagositosis yang dilakukan oleh sel makrofag (Kresno, 2001).

Obat-obatan yang berkembang di masyarakat salah satunya berasal dari mikroorganisme, seperti dari kelompok bakteri asam laktat (BAL), yaitu Lactobacillus plantarum. Produk bioaktif yang dihasilkan bakteri asam laktat pada dinding sel luarnya diantaranya eksopolisakarida (Savadogo et al., 2006).

Eksopolisakarida (EPS) merupakan gula polimer yang disekresikan oleh mikroorganime ke lingkungan. Fungsi EPS sebagai perlindungan diri bagi mikroorganisme penghasilnya. EPS berperan di industri makanan dan kesehatan, karena mampu menstimulasi sistem imun, sebagai anti mutagen dan 
aktivitas antitumor (Harutoshi, 2013). EPS diketahui memiliki efek imunomodulator pada dosis minimum $10 \mathrm{mg} / \mathrm{kg}$ BB mencit (Bravo et al., 2011).

Salah satu sumber nutrisi yang dapat menjaga kesehatan tubuh selain vitamin adalah mineral, contohnya selenium yang berfungsi terhadap sistim kekebalan tubuh. Pemberian selenium mampu menghasilkan peningkatan pada sel lymphokineactivated killer cell dan makrofag (Schumacher dan Roy, 1987). Selenium juga dapat meningkatkan produksi sel T sitotoksik dan sel natural killer (sel $\mathrm{NK}$ ), sehingga dapat meningkatkan kapasitas perlindungan terhadap penyakit kanker (Thomson, 2004). Dosis selenium dapat ditambahkan sebanyak $200 \mu \mathrm{g} /$ hari (Egbuna et al., 2020). Hasil penelitian Ju et al. (2013) bahwa peningkatan dosis Se diatas kebutuhan nutrisi dapat menimbulkan resiko resistensi insulin dan diabetes tipe 2 akibat kelebihan produksi Selenoprotein. Meskipun mekanisme diabetogeniknya masih belum jelas, asupan tinggi Se meningkatkan aktivitas atau produksi selenoprotein termasuk GPx1, MsrB1, Sel S, dan Sel P. Regulasi tersebut mengurangi reactive oxygen species (ROS) intraseluler yang merupakan bagian dari proses metabolisme, kemudian mengarah ke hiperinsulinemia kronis. Asupan Se tinggi dapat mempengaruhi fungsi regulator utama untuk glikolisis, glukoneogenesis, dan lipogenesis. Penambahan Selenium Oksiklorida dengan dosis berbeda bertujuan untuk meningkatkan potensi imunomodulator dari EPS L plantarum Y-1.2 melalui aktivitas dan fagositosis sel makrofag.

\section{BAHAN DAN CARA KERJA}

Bahan yang digunakan adalah isolat $L$. plantarum Y-1.2 diisolasi dari produk Yoghurt koleksi Pusat Penelitian Bioteknologi - LIPI, bakteri Staphylococcus aureus diisolasi dari susu sapi merupakan koleksi Laboratorium Bakteriologi, Fakultas Kedokteran Hewan, Institut Pertanian Bogor, serbuk Selenium Oksiklorida $\left(\mathrm{SeOCl}_{2}\right.$, Merck 336157), MRSb (deMann Ragosa Sharpe broth, Merck 69966), Hewan coba mencit galur DDY (Deutschland Denken Yoke).
Pembuatan Prakultur Isolat L. plantarum Y-1.2 dan Produksi EPS (Tang et al., 2015)

Persiapan prakultur dengan menambahkan $0,5 \%$ inokulum Bakteri $L$ plantarum $Y-1.2$ ke dalam $50 \mathrm{ml}$ MRS cair, kemudian diinkubasi pada suhu $37^{\circ} \mathrm{C}$ selama 18-20 jam. Produksi EPS menggunakan medium fermentasi mengandung susu skim $12 \%$, pepton (oxoid) $1 \%$, glukosa (oxoid) $1,5 \%$, dan $\mathrm{K}_{2} \mathrm{HPO}_{4} \quad 0,1 \%$. Semua bahan dilarutkan dengan akuades hingga homogen dan disterilkan menggunakan autoklaf pada $121{ }^{\circ} \mathrm{C}$ selama 15 menit. Sejumlah $3 \%$ prakultur $L$ plantarum $\mathrm{Y}-1.2$ (konsentrasi $2 \times 10^{6}$ sel per ml) diinokulasikan ke media fermentasi untuk memproduksi EPS. Selanjutnya diinkubasi pada suhu $37{ }^{\circ} \mathrm{C}$ selama 48 jam dengan putaran $150 \mathrm{rpm}$. Persentase rendemen biomasa sel L. plantarum Y-1.2 yaitu berat biomasa sel kering (g) dibagi berat biomasa sel basah (g) dikalikan $100 \%$.

\section{Ekstraksi dan Kuantifikasi EPS (Savadogo et al., 2004)}

Kultur segar $L$ plantarum $Y-1.2$ berumur 48 jam disentrifugasi pada kecepatan $11.000 \mathrm{xg}$ selama 10 menit pada suhu $4{ }^{\circ} \mathrm{C}$ untuk memisahkan pelet sel dan supernatan. Sebanyak dua kali volume etanol dingin ditambahkan ke dalam supernatan, kemudian disimpan pada suhu $4{ }^{\circ} \mathrm{C}$ semalam. Endapan yang terbentuk dikumpulkan dan diresuspensi dengan akuades disentrifus ( $2500 \mathrm{x}$ g selama 20 menit), dan ditambah etanol dua kali volume. Sampel disentrifus kembali dengan kecepatan 2500xg selama 20 menit. Pelet diambil ditimbang sebagai berat basah EPS(g) dan dikeringkan pada $100{ }^{\circ} \mathrm{C}$, kemudian ditimbang sebagai crude EPS kering (g). Persentase rendemen EPS yang diperoleh yaitu Crude EPS kering (g) dibagi berat basah EPS (g) dikalikan 100\%.

\section{Analisis senyawa eksopolisakarida}

Crude EPS dihidrolisis dengan asam sulfat $80 \%$ selama 8 jam. kemudian dinetralisir dengan $\mathrm{Na}_{2} \mathrm{CO}_{3}$. Sampel disaring menggunakan millipore $0,45 \mu$ l. Gas pada larutan dihilangkan menggunakan ultrasonik selama 30 menit, kemudian $20 \mu \mathrm{l}$ larutan disuntikkan 
kedalam injektor alat Kromatografi cair kinerja tinggi (KCKT; Waters 2695, temperatur kolom $35^{\circ}$ $\mathrm{C}$, fase gerak asetonitril $80 \%$, laju alir $1,4 \mathrm{ml} /$ menit) Aminex ${ }^{\circledR} H P X-87 \mathrm{H}$ dengan kolom $300 \mathrm{~mm} \times 7,8$ mm dan detektor indeks revlaktif.

\section{Penetapan kadar glukosa dalam sampel eksopolisakarida}

Kadar glukosa ditentukan menggunakan metode fenol sulfat menurut DuBois et al. (Bukola dan Fashogbon, 2020). Larutan baku pembanding glukosa dengan konsentrasi berturut-turut 20; 40; 60; 80 dan 100bpj masing-masing dipipet $0,5 \mathrm{~mL}$ ditambahkan $0,25 \mathrm{~mL}$ fenol $5 \%$ dan $1,25 \mathrm{~mL}$ asam sulfat pekat dalam tabung reaksi, dikocok hingga homogen, didiamkan selama 10 menit, kemudian dididihkan selama 15 menit. Serapan larutan diukur dengan spektrofotometer UV-Vis (Shimadzu 1800) pada panjang gelombang $490 \mathrm{~nm}$. Crude EPS sebagai sampel diperlakukan sama dan akuades digunakan sebagai blanko. Pembacaan serapan yang diperoleh digunakan untuk membuat kurva kalibrasi baku pembanding glukosa dan menetapkan persamaan garis regresi. Hasil serapan sampel dihitung ke persamaan garis regresi untuk memperoleh kadar glukosa dalam larutan uji yang terukur (Kusmiati et al., 2007).

\section{Penetapan kadar protein dalam sampel eksopolisakarida}

Penentuan kadar protein menggunakan metode Lowry yang dimodifikasi Hartree (Hanne et al., 2018). Crude eksopolisakarida L plantarum Y-1.2 $1000 \mathrm{ppm}$ dalam $\mathrm{NaOH} 0,75 \mathrm{M}$ ditambah $0,9 \mathrm{~mL}$ larutan A $(2 \mathrm{~g}$ per $\mathrm{L}$ kalium natrium tartrat $\left(\mathrm{KNaC}_{4} \mathrm{H}_{4} \mathrm{O}_{6} \cdot 4 \mathrm{H}_{2} \mathrm{O}\right)$ dan $100 \mathrm{~g}$ per $\mathrm{L}$ natrium karbonat $\left(\mathrm{Na}_{2} \mathrm{CO}_{3}\right)$ dalam $\left.0,5 \mathrm{M} \mathrm{NaOH}\right)$. Larutan diinkubasi selama 10 menit pada $50^{\circ} \mathrm{C}$ dan didinginkan hingga suhu kamar. Selanjutnya ditambahkan $1 \mathrm{~mL}$ larutan $\mathrm{B}(0,2 \mathrm{~g}$ per $\mathrm{L}$ $\mathrm{KNaC}_{4} \mathrm{H}_{4} \mathrm{O}_{6} \cdot 4 \mathrm{H}_{2} \mathrm{O}$ dan 0,1 g per $\mathrm{L} \mathrm{CuSO}_{4} \cdot 5 \mathrm{H}_{2} \mathrm{O}$ dalam $0,1 \mathrm{M} \mathrm{NaOH}$ ) dan dibiarkan selama 10 menit, selanjutnya ditambah $3 \mathrm{~mL}$ larutan $\mathrm{C}$ (Phenol FolinCiocalteu dalam $\mathrm{H}_{2} \mathrm{O} \quad(1: 16 \quad \mathrm{v} / \mathrm{v})$. Kemudian diinkubasi selama 10 menit pada $50{ }^{\circ} \mathrm{C}$. Kurva standar yaitu larutan bovine serum albumin (BSA); 50; 100; 200; 300; 400 dan 500 bpj. Serapan larutan diukur dengan spektrofotometer uv-vis pada panjang gelombang $750 \mathrm{~nm}$.

\section{Pengujian Efek Penambahan $\mathrm{SeOCl}_{2}$ terhadap peningkatan potensi imunomodulator Eksopolisakarida L. Plantarum}

Percobaan dilakukan secara in vivo menggunakan hewan coba mencit galur DDY (Deutschland Denken Yok) berat 23-27 g sebelum aklimatisasi, umur 2-3 bulan, jenis kelamin jantan. Hewan dipelihara di kandang secara terpisah berdasarkan kelompok perlakuan. Percobaan dilakukan secara oral selama 14 hari, setiap kelompok perlakuan dengan 4 ulangan. Kelompok perlakuan sebagai berikut: Kelompok I (Kontrol positif 0,5ml stimuno), Kelompok II (Kontrol negatif, crude EPS dosis $50 \mathrm{mg} / \mathrm{kg} \mathrm{BB}$ ), Kelompok III, Kontrol normal (0,5ml akuades), Kelompok IV (Crude EPS $+\mathrm{SeOCl}_{2} 0,13 \mu \mathrm{g}$ ), Kelompok V Crude

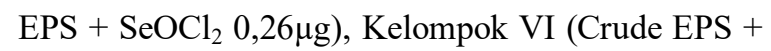
$\mathrm{SeOCl}_{2} \quad 0,52 \mu \mathrm{g}$ ). Pemberian dosis ini berdasarkan hasil penelitian Egbuna et al. (2020), bahwa selenium dapat ditambahkan sebanyak $200 \mu \mathrm{g} / \mathrm{hari}$. Penggunaan pada mencit dikonversikan dengan mengalikan 0,0026 , sehingga diperoleh $0,52 \mu \mathrm{g}$.

\section{Analisis fagositosis makrofag}

Percobaan pada hari ke 15, setiap mencit diinfeksi intraperitoneal dengan suspensi bakteri $S$. aureus sebanyak $0,5 \mathrm{ml}$ dengan konsentrasi $1 \times 10^{8}$ $\mathrm{sel} / \mathrm{mL}$ dan dibiarkan selama 1 jam. Kemudian mencit di eutanasia. Bagian perut dibersihkan dengan menggunakan etanol $70 \%$ dan dibedah diatas papan bedah. Cairan peritoneum dibuat preparat ulas pada gelas objek dan difiksasi dengan metanol kemudian dilakukan pewarnaan dengan Giemsa (Herawati et al., 2015). Pengamatan dilakukan di bawah mikroskop dengan perbesaran 10x100 kali. Aktivitas fagositosis ditetapkan berdasarkan jumlah bakteri $S$. aureus yang difagositosis oleh 50 sel fagosit yang aktif.

\section{Penetapan nilai aktivitas dan kapasitas fagositosis} Aktivitas Fagositosis. Nilai aktivitas fagositosis ditetapkan berdasarkan jumlah sel makrofag yang secara aktif melakukan proses fagositosis dalam 100 sel makrofag yang dinyatakan dalam persen. 
$\%$ Aktivitas $=\frac{\text { Jumlah makrof ag aktif }}{\text { Jumlah makrofag keseluruhan }} \times 100 \%$

Peningkatan aktivitas fagositosis kelompok uji terhadap kelompok kontrol negatif

(Rata-rata aktivitas fagositosis kel uji - Rata-rata aktivitas fagositosis kel kontrol negatif) x 100\%

(Rata-rata Aktivitas fagositosis kelompok kontrol negatif)

Kapasitas fagositosis. Nilai kapasitas fagositosis ditetapkan berdasarkan banyaknya jumlah bakteri $S$. aureus yang difagositosis oleh 50 sel makrofag aktif

$$
\text { kapasitas fagositosis }=\frac{\text { Jumlah Bakteri } U_{j i}}{\text { Jumlah sel makrof } a g \text { aktif }}
$$

Peningkatan Kapasitas fagositosis kelompok uji terhadap kelompok kontrol negatif

(Rata-rata kapasitas fagositosis kel uji-Rata-rata kapasitas fagositosis kel kontrol negatif) x 100\%

(Rata-rata kapasitas fagositosis kelompok kontrol negatif)

\section{Analisis Data}

Data hasil pengamatan efek perlakuan Selenium Oksiklorida terhadap mencit yang diberi eksopolisakarida dari $L$. plantarum melalui pengukuran aktivitas dan kapasitas fagositosis sel makrofag peritoneum mencit dianalisis dengan ANOVA satu arah, kemudian bila terdapat perbedaan dilakukan uji lanjutan Tukey.

\section{HASIL}

\section{Karakterisasi dan analisis EPS}

Hasil pengkulturan L. plantarum dalam media cair MRS diamati di bawah mikroskop menunjukkan bahwa sel berbentuk batang berwarna biru/ungu dan termasuk bakteri Gram positif. Perolehan berat Biomasa sel L. plantarum sebesar $0.1187 \pm 0,0013$ gram per $50 \mathrm{ml}$ media fermentasi, dengan rendemen sebesar $9.43 \pm 0,1058 \%$. Bobot crude eksopolisakarida diperoleh sebesar $3,947 \pm 0,06$ gram per $50 \mathrm{ml}$, dengan rendemen sebesar $80.72 \pm 1,59 \%$.

Crude EPS yang diperoleh digunakan untuk identifikasi monomer menggunakan KCKT, pengujian imunomodulator melalui aktivitas dan kapasitas fagositosis sel makrofag, analisis glukosa dan analisis protein.

Identifikasi senyawa monomer sampel EPS $L$. plantarum dapat dilihat dari waktu retensi baku pembanding (BP) glukosa (Tabel 1) dan waktu retensi sampel EPS (Gambar 1).

Kalibrasi larutan glukosa BP dengan metode Fenol-Sulfat diukur pada panjang gelombang 490 $\mathrm{nm}$ menghasilkan persamaan garis regresi $\mathrm{y}=$ $0,0431+0,00285 \mathrm{x}$, dengan koefisien korelasi mendekati 1 yaitu: 0,9877, menunjukkan ada hubungan linear antara konsentrasi baku pembanding glukosa dengan serapan cahaya tampak, dimana kenaikan serapan cahaya tampak sebanding dengan kenaikan konsentrasi glukosa (Gambar 2).

Tabel 1. Waktu retensi gula standar (Retention time of monomer carbohydrate standard)

\begin{tabular}{ccc}
\hline No & $\begin{array}{c}\text { Monomer } \\
\text { (Monomer) }\end{array}$ & $\begin{array}{c}\text { Waktu retensi } \\
\text { (Retention time) }\end{array}$ \\
\hline 1 & Fruktosa (Fructose) & 3.882 \\
2 & Glukosa (Glucose) & 4.234 \\
3 & Sukrosa (Sucrose) & 5.667 \\
4 & Maltosa (Maltose) & 6.330 \\
5 & Laktosa (Lactose) & 7.137 \\
\hline
\end{tabular}

Tabel 2. Kadar glukosa dan protein Eksopolisakarida L. plantarum (Glucose and protein content of Exopolysaccharide L. plantarum)

\begin{tabular}{cc}
\hline $\begin{array}{c}\text { Karakteristik } \\
\text { (Characteristics) }\end{array}$ & $\mathbf{\%}$ \\
\hline Kadar glukosa (Glucose content) & $41,46 \pm 0,62$ \\
Kadar protein (Protein content) & $3,95 \pm 0,25$ \\
\hline
\end{tabular}



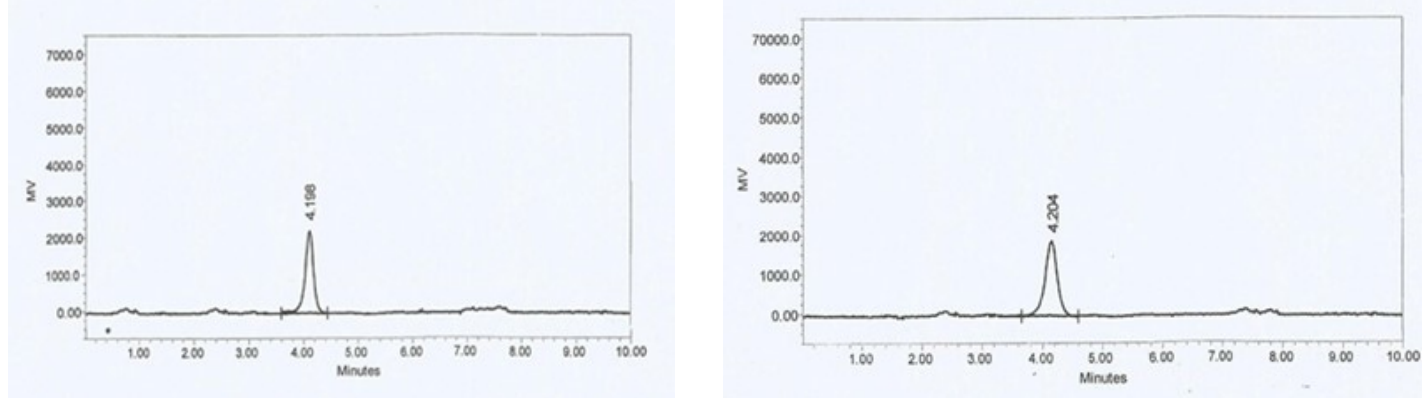

Gambar 1. Kromatogram KCKT sampel eksopolisakarida dari L. plantarum, $\mathrm{n}=2$. (Chromatogram of Exopolysaccharide from L. plantarum, $n=2$ )

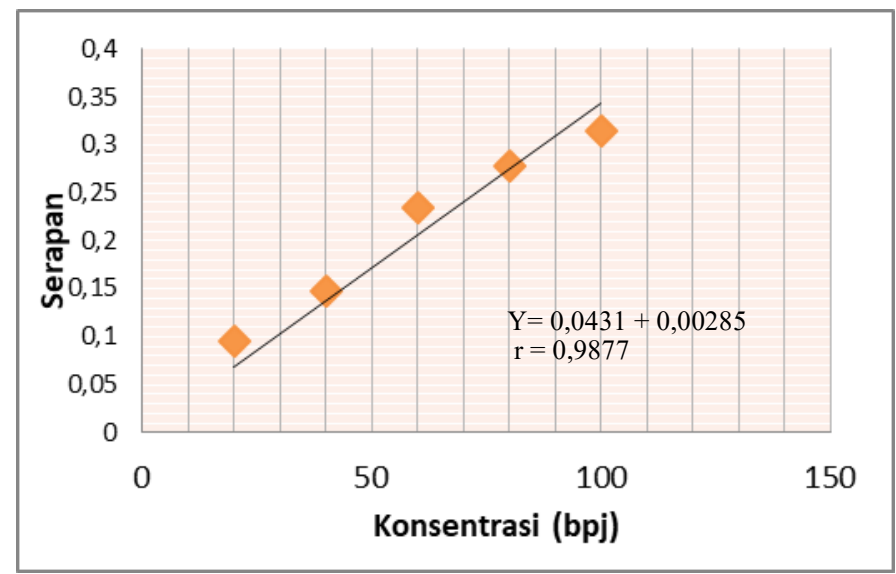

Gambar 2. Kurva kalibrasi baku pembanding glukosa menggunakan spektrofotometer UV-VIS pada $\lambda 490$ $\mathrm{nm}$ (calibration curves of Glucose standard using a UV-VIS spectrophotometer at $\lambda 490 \mathrm{~nm}$ )

Hasil pengukuran kadar glukosa dan protein dalam EPS L. plantarum dapat dilihat pada Tabel 2. Pengujian pemberian selenium oksid klorida secara in vivo terhadap hewan coba yang diberi EPS L. plantarum dilakukan di kandang percobaan. Hasil pengukuran berat hewan coba setelah tahap aklimatisasi berkisar antara 31-39 gram.

\section{Aktivitas dan kapasitas fagositosis sel makrofag pada cairan Peritoneum \\ Perlakuan $\mathrm{SeOCl}_{2}$ terhadap mencit yang diberi diet EPS L. plantarum dan diinduksi $S$. aureus diuji efeknya terhadap aktivitas dan kapasitas fagositosis sel makrofag cairan}

peritonium. Hasil pengamatan terlihat pada Tabel 4. Sel makrofag cairan peritoneum mencit setelah diberikan EPS dan diinduksi dengan bakteri $S$. aureus, dapat dilihat pada Gambar 5a dan 5b.

\section{PEMBAHASAN}

L. plantarum merupakan jenis bakteri asam laktat. Sel L. plantarum memiliki bentuk seperti batang, bervariasi bentuk panjang dan ramping sampai kokobasilus pendek $(15-20 \mu \mathrm{m})$. Sering ditemukan dalam bentuk rantai, terutama pada fase pertumbuhan logaritma. Lactobacillus merupakan kelompok bakteri Gram positif, yaitu bakteri yang mempertahankan zat warna kristal violet pada 
Tabel 4. Aktivitas dan kapasitas fagositosis sel makrofag dalam cairan peritoneum (Phagocytic activity and capacity of macrophage cells in the peritoneal fluid)

\begin{tabular}{|c|c|c|c|c|c|c|}
\hline \multirow{2}{*}{$\begin{array}{c}\text { Fagositosis } \\
\text { (Phagocytosis) }\end{array}$} & \multicolumn{6}{|c|}{ Kelompok Perlakuan (Group) } \\
\hline & $\mathbf{I}$ & II & III & IV & $\mathbf{V}$ & VI \\
\hline $\begin{array}{l}\text { Aktivitas } \\
\text { fagositosis } \\
\text { (Phagocytic } \\
\text { activity) }(\%)\end{array}$ & $85,2^{a} \pm 1,30$ & $62,0^{\mathrm{e}} \pm 1,58$ & $51,4^{\mathrm{f}} \pm 1,14$ & $71,2^{\mathrm{d}} \pm 1,30$ & $73,6^{\mathrm{c}} \pm 1,14$ & $79,4^{b} \pm 0,55$ \\
\hline $\begin{array}{l}\text { Kapasitas } \\
\text { fagositosis } \\
\text { (Phagocytic } \\
\text { Capacity (sel) }\end{array}$ & $682,4^{\mathrm{a}} \pm 9,91$ & $498^{\mathrm{e}} \pm 12,65$ & $413^{\mathrm{f}} \pm 9,22$ & $571,6^{\mathrm{d}} \pm 9,32$ & $590,4^{c} \pm 8,53$ & $639,4^{\mathrm{b}} \pm 4,51$ \\
\hline
\end{tabular}

--Keterangan : Angka diikuti huruf berbeda menunjukkan ada perbedaan yang nyata $(\mathrm{a}=0.05)$

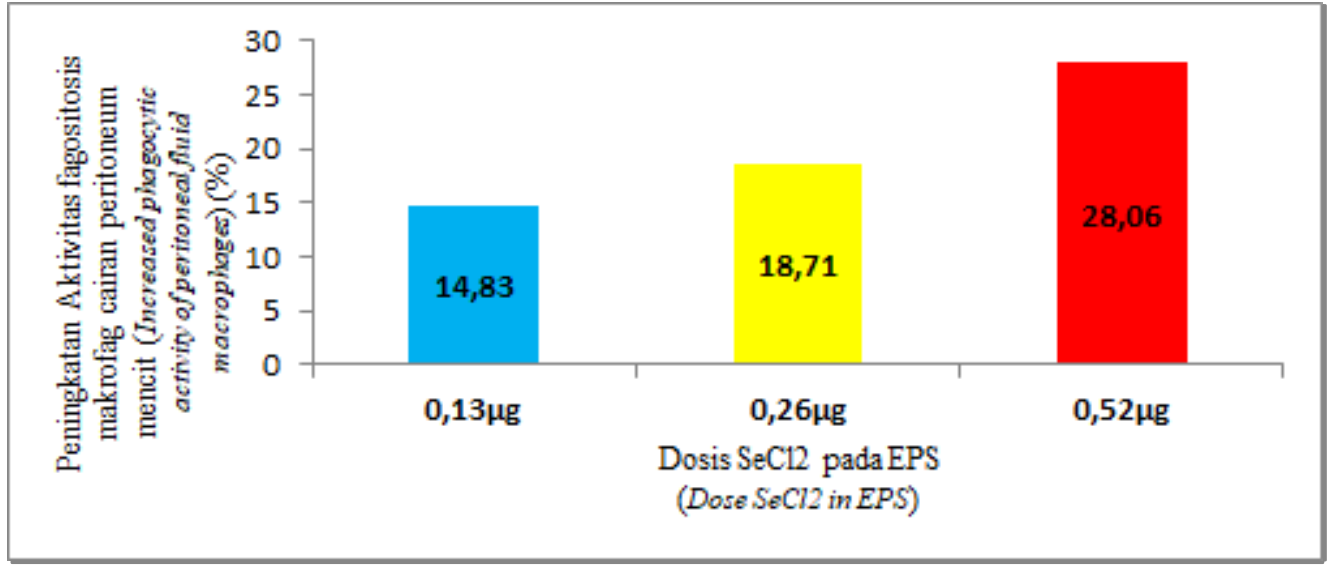

Gambar 3. Peningkatan aktivitas fagositosis makrofag cairan peritoneum mencit setelah pemberian berbagai variasi dosis $\mathrm{SeOCl}_{2}$ yang ditambahkan kedalam EPS selama 14 hari (Increased phagocytic activity of macrophage peritoneal fluid in mice after administration of various doses of $\mathrm{SeOCl}_{2}$ added to EPS for 14 days).

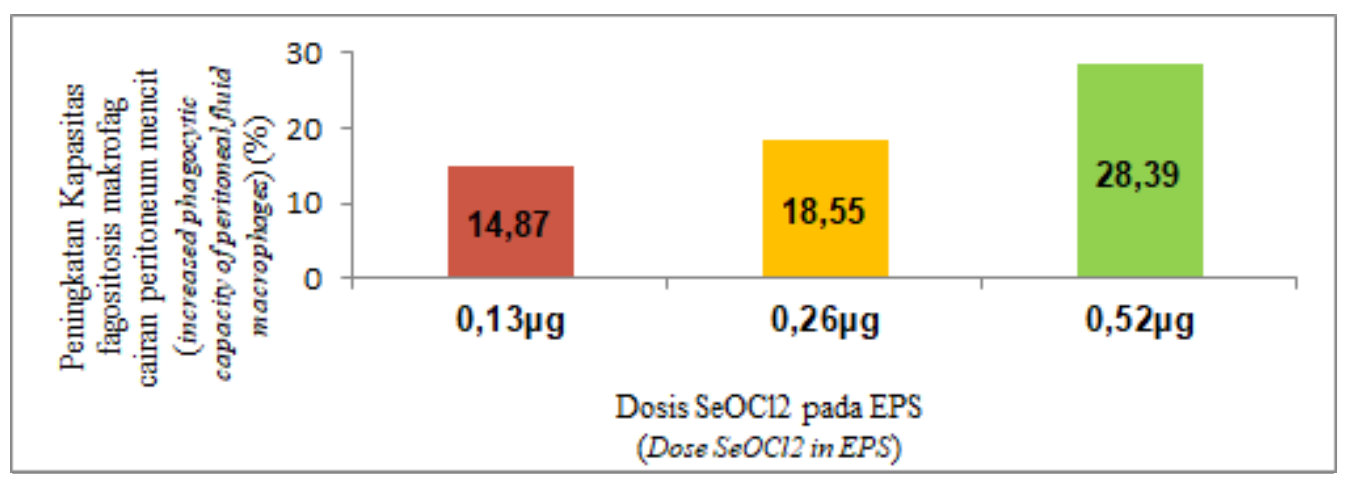

Gambar 4. Peningkatan kapasitas fagositosis makrofag cairan peritoneum mencit setelah pemberian berbagai variasi dosis $\mathrm{SeOCl}_{2}$ yang ditambahkan kedalam EPS selama 14 hari (Increased phagocytic capacity of macrophage peritoneal fluid in mice after administration of various doses of SeOCl2 added to EPS for 14 days). 


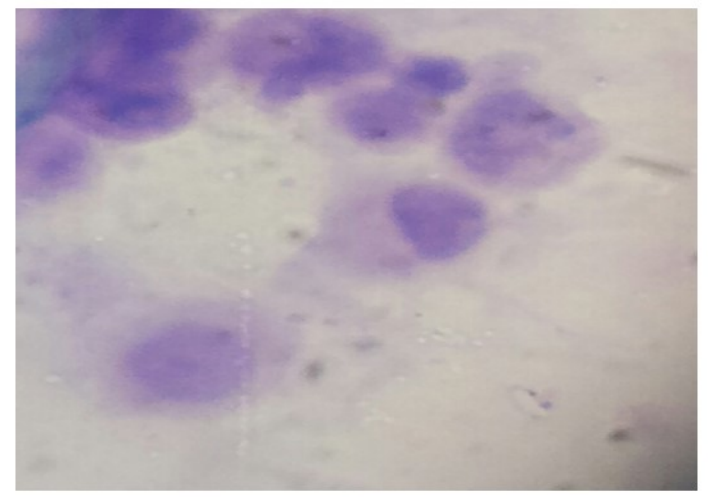

Gambar 5a. Sel makrofag sebelum memfagosit $S$ aureus (1000x, Leica) (macrophage cells before phagocyte of $S$. aureus (1000x, Leica)

proses pewarnaan. Sel berwarna biru atau ungu dibawah mikroskop.

Karakterisasi dan analisis eksopolisakarida. EPS hasil ekstraksi dari kultur L. plantarum Y-1.2 dikarakterisasi monomernya menggunakan kromatografi cair kinterja Tinggi (KCKT). Hasil menunjukkan bahwa sampel EPS memiliki waktu retensi 4.198 dan 4.204 menit (Gambar 1), dibandingkan terhadap waktu retensi monomer standar pada Tabel 1 mendekati waktu retensi glukosa (4.234 menit). Hasil menunjukkan monomer EPS dari L. plantarum $Y$-1.2 yang teridentifikasi menggunakan KCKT adalah glukosa. Wang et al., 2015 melaporkan bahwa L. plantarum menghasilkan EPS dengan komposisi monomer glukosa dan galaktosa. Namun pada EPS ini teridentifikasi hanya jenis monomer glukosa.

Analisis glukosa pada EPS L plantarum $Y-1.2$ menggunakan metode fenol sulfat dihitung terhadap kurva standar Glukosa (Gambar 2) dengan hasil mencapai 41,46\% $\pm 0,62$, hal ini menunjukkan EPS berupa Crude masih mengandung senyawa lain selain monomernya (Tabel 1). Analisis protein perlu dilakukan karena senyawa aktif obat yang mengandung protein akan menyebabkan peningkatan efek samping pada tubuh seseorang yang sensitif terhadap protein, sehingga mampu memicu timbulnya reaksi alergi seperti gatal atau mual. Semakin kecil kadar protein yang terkandung dalam bahan uji, maka akan semakin baik karena kemungkinan menimbulkan reaksi alergi semakin

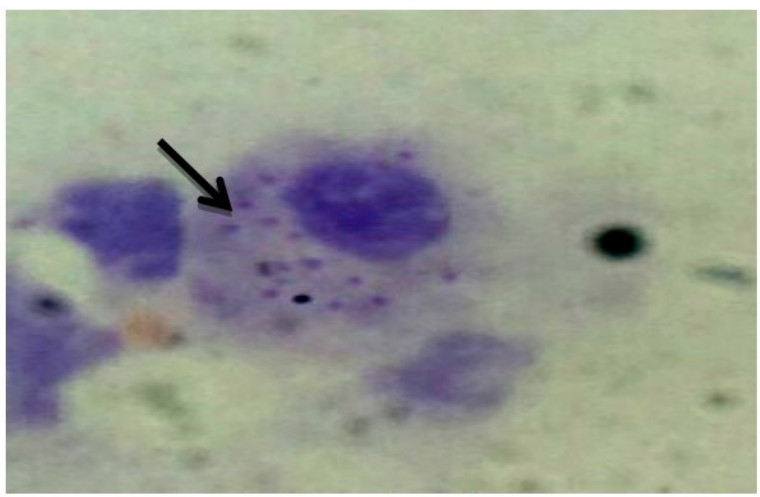

Gambar 5b. Fagositosis bakteri $S$ aureus oleh Sel makrofag (1000x, Leica) (bacterial of $S$. aureus phagocytosis by macrophage cells (1000x, Leica)

kecil. Hasil analisis kadar protein dengan metode Lowry menggunakan standar bovine serum albumin (BSA) sebesar 3,95\% $\pm 0,25$ (Tabel 2).

Uji in vivo pada hewan coba. Mencit galur DDY (Deutschland Denken Yoke) yang digunakan ditimbang pasca adaptasi dan dikelompokan menjadi enam kelompok perlakuan. Perlakuan merupakan penambahan $\mathrm{SeOCl}_{2}$ terhadap mencit yang diberi EPS L. plantarum Y-1.2 dan diinduksi $S$. aureus. Hasil pengamatan aktivitas dan kapasitas fagositosis sel makrofag cairan peritoneum mencit menunjukkan bahwa kelompok kontrol positif yang diberikan stimuno memiliki aktivitas dan kapasitas fagositosis yang lebih tinggi dibandingkan dengan kelompok lainnya. Peningkatan aktivitas dan kapasitas fagositosis sel makrofag peritoneum mencit juga terjadi pada sampel dengan penambahan dosis $\mathrm{SeOCl}_{2}$ (Tabel 4). Hasil penelitian Pan et al. (2015), menjelaskan bahwa EPS dan Se-EPS memiliki efek stimulasi sinergis ganda pada proliferasi limfosit B atau T. Hasil menunjukkan bahwa konsentrasi EPS dan Se-EPS yang berbeda dapat merangsang kekebalan sistem dengan mempromosikan proliferasi limfosit.

Mekanisme fagositosis dalam makrofag dapat terjadi peningkatan oksigen sehingga menghasilkan suatu metabolit oksigen mikrobisidal yang dilepas selama fagositosis yaitu ROIs (reactive oxygen intermediates) dan terjadi ikatan mikroba dengan sel fagositosis membentuk 
fagolisosom. Terbentuknya fagolisosom dapat mengaktifkan beberapa enzim yang dapat mengubah oksigen menjadi anion superoksida, radikal hidrogen, single oxygen, myeloperoxidase, hidrogen peroksida $\left(\mathrm{H}_{2} \mathrm{O}_{2}\right)$ yang berinteraksi dan menghasilkan metabolit oksigen toksik yang dapat membunuh kuman (Abbas dan Lichtman, 2005). Mekanisme lainnya yaitu makrofag menghasilkan reactive nitrogen intermediates dengan bantuan enzim salah satunya adalah nitrit oxide synthesis (iNOS). Dalam proses fagolisosom terjadi reaksi fagosit oksidase antara nitrit oksida dengan $\mathrm{H}_{2} \mathrm{O}_{2}$ yang menghasilkan peroksi nitrit radikal yang reaktif dalam membunuh subtansi asing dan mikroba.

Aktivitas fagositosis. Penambahan $\mathrm{SeOCl}_{2}$ secara oral selama 14 hari dan dilanjutkan dengan penyuntikan suspensi bakteri S.aureus secara intraperitoneal pada hari ke-15. Bakteri S. aureus dapat bertahan hidup secara intraseluler dalam fagosit termasuk neutrofil (Thwaites dan Gant, 2011) dan makrofag (Kubica et al., 2008), sehingga bertahan terhadap pengobatan antibiotik. Di antara mekanisme resistensi $S$. aureus terhadap fagositosis, kemampuannya untuk membelah rantai antibodi opsonik, menggunakan protease V8 (staphylococcal serine protease A, SspA) telah dijelaskan Nair et al. (2000). Enzim proteolitik dapat mendegradasi agen peptida antimikroba inang dan komponen jaringan (Aslam et al., 2013).

Kapasitas fagositosis. Gambar 4 menunjukkan adanya peningkatan kapasitas fagositosis makrofag cairan peritoneum mencit setelah adanya penambahan Selenium Oksiklorida. Semakin tinggi dosis pemberian selenium klorid oksid, menunjukkan peningkatan kapasitas fagositosis sel makrofag. Makrofag yang mengandung sel bakteri $S$ aureus ditunjukkan dengan adanya titik-titik yang berwarna keunguan didalam sel makrofag. Sitoplasma yang dibentuk oleh sel makrofag akan berwarna merah keunguan, tetapi inti selnya akan berwarna lebih pekat dibandingkan sitoplasma yang terbentuk. Penggunaan bakteri uji $S$. aureus sebagai antigen, karena $S$. aureus merupakan bakteri Gram positif sehingga mampu mengikat warna giemsa dengan lebih jelas, berbentuk bulat (kokus) sehingga mempermudah proses perhitungan aktivitas fagositosis di bawah mikroskop (Gambar 5a dan 5b), serta memiliki kemampuan membentuk sejumlah toksin dan enzim digestif.

Aktivitas dan kapasitas fagositosis sel makrofag yang diberikan $\mathrm{SeOCl}_{2}$ dalam eksopolisakarida meningkat dibandingkan dengan sel makrofag yang tidak diberikan $\mathrm{SeOCl}_{2}$. Ini menunjukkan bahwa pemberian $\mathrm{SeOCl}_{2}$ pada sel makrofag sangat mempengaruhi nilai aktivitas dan kapasitas fagositosis. Nilai persen aktivitas dan kapasitas fagositosis sel makrofag kelompok uji lebih kecil jika dibandingkan dengan kontrol positif. Hal ini dikarenakan pada kelompok kontrol positif ditambahkan suatu zat konvensional yang benar benar memiliki efek sebagai imunomodulator.

Eksopolisakarida dan $\mathrm{SeOCl}_{2}$ diketahui mampu menstimulasi respon imun. Pada EPS pemberiannya akan meningkatkan sitokin (Pan et al, 2015). Peningkatan sitokin yang merupakan faktor pengaktif sel makrofag akan menstimulasi reaktivitas imun, baik yang bersifat spesifik maupun non spesifik. Sitokin yang terkandung akan memberikan kemampuan sel makrofag untuk menghancurkan antigen menjadi meningkat (Wahyudi dan Priyanto, 2010). Selenium dapat meningkatkan produksi sel $\mathrm{T}$ sitotoksik dan sel natural killer (sel NK) (Fardiaz, 1992).

\section{KESIMPULAN}

Suplementasi selenium dapat meningkatkan kontrol respons imun in vivo terhadap $S$. aureus. Perlakuan diet Eksopolisakarida (50mg/kg BB), yang diekstraksi dari kultur L. plantarum $Y$-1.2 dan pemberian $\mathrm{SeOCl}_{2}$ hingga dosis $0,52 \mu \mathrm{g}$, dapat meningkatkan aktivitas dan kapasitas fagositosis sel makrofag peritoneum mencit putih (Mus musculus) jantan yang diinduksi dengan S.aureus (in vivo).

\section{DAFTAR PUSTAKA}

Abbas, A., Lichtman, A.H. and Pober J.S., 2005. Cellular and Molecular Immunology. 5th ed. Philadelphia: Elsevier-Saunder,4-15,22-3,65-80,81-103,182- 7,247 $-53,258-9,266,268-9,279-80,290-5$

Aslam, R., Marban, C., Corazzol, C., Jehl, F., Delalande, F., Van Dorsselaer, A., et al., 2013. Cateslytin, a 
chromogranin A derived peptide is active against Staphylococcus aureus and resistant to degradation by its proteases. PLoS One. 8:e68993.

Baratawidjaja, K.G., 2004. Imunologi Dasar. Edisi 7. Jakarta: Balai Penerbit Fakultas Kedokteran Universitas Indonesia. p. 6-20, 71-83,412-28.

Bravo, A.R., Valera, M.J., Moreno, E. and Guerra, V., 2011. Biological response modifier activity of an exopolysaccharide from Paenibacillus jamilae CP-7. Clinical and Diagnostic Laboratory Imunology, 8(4), pp. 706-710.

DuBois, M., et al., Colorimetric Method for Determination of Sugars and Related Substances. Analytical Chemistry, 1956. 28(3), pp. 350-356. In: Bukola Adebayo-Tayo, Racheal Fashogbon. 2020. In vitro antioxidant, antibacterial, in vivo immunomodulatory, antitumor and hematological potential of exopolysaccharide produced by wild type and mutant Lactobacillus delbureckii subsp. Bulgaricus. Heliyon 6 e03268. Elsevier Ltd.

Egbuna, C., Kumar, S., Ifemeje, J.C., Kurhekar, J.V., Phytochemistry: Volume 2: Pharmacognosy, Nanomedicine, and ContemporaryIssues. https:// umm.edu/health/medical/altmed/supplement/ selenium. [accessed 11 Mei 2020]

Erickson, K.L., Medina, E.A. and Hubbard, N.E., 2000 Micronutrients and innate immunity. Journal Infectious Diseases 182, pp. S5-S10. PMID: 10944478

Fardiaz, S., 1992. Mikrobiologi pangan I. Jakarta: PT Gramedia Pustaka Utama. pp. 29-41.

Hanne, K., Mæhre, Lars Dalheim, Guro, K., Edvinsen, Edel, O., Elvevoll, and Ida-Johanne, Jensen., 2018. Protein Determination-Method Matters. Journal of Foods, 7 (5), pp.1-11 doi:10.3390/foods7010005

Harutoshi, T., 2013. Exopolysaccharides of lactic acid bacteria for food and colon health applications. Intech. http:// dx.doi.org/10.5772/50839 [accessed 11 Mei 2020]

Herawati, I., Husin, U.A., Sudigdoadi, S., 2015. Pengaruh Ekstrak Etanol Propolis Terhadap Aktivitas dan Kapasitas Fagositosis pada Kultur Makrofag yang Diinfeksi Enteropathogenic Escherichia coli (EPEC) MKB, 47(2). http://dx.doi.org/10.15395/mkb. v47n2. 460

Hibbs, J.B., Taintor, R.R. and Vavrin, Z., 1987. Macrophage cytotoxicity: Role for L-arginine deiminase and imino nitrogen oxidation to nitrite. Science, 235, pp. 473-476. doi:10.1126/science.2432665 [Crossref] [PubMed], [Web of Science $\left.{ }^{\circledR}\right]$, [Google Scholar]

Jun, Zhou, Kaixun, Huang, Xin, Gen Lei., 2013. Selenium and diabetes-Evidence from animal studies. Joural Free Radical Biology and Medicine, 65. July 2013 DOI 10.1016/j.freeradbiomed.2013.07.012

Schumacher-Kiremidjian, and Roy, M., 1998. Selenium and immune function. Z Ernahrungswiss, 37(1), pp. 50 56. PMID: 9558729

Kresno, S.B., 2001. Imunologi Diagnosis dan Prosedur Laboratorium. Edisi IV. Jakarta: Balai Penerbit Fakultas Kedokteran Universitas Indonesia. pp. 4-34 172-73.

Kubica, M., Guzik, K., Koziel, J., Zarebski, M., Richter, W., Gajkowska, B., et al., 2008. A potential new pathway for Staphylococcus aureus dissemination: the silent survival of $S$. aureus phagocytosed by human monocyte-derived macrophages. PLoS One 3: e1409.

Kusmiati, Tamat, S.R., Nuswantara, dan Isnaini, N., 2007. Produksi dan penetapan kadar $\beta$-glukan dari tiga galur Saccharomyces cerevisiae dalam media mengandung molase. Jurnal Ilmu Kefarmasian Indonesia, (5), pp. 7-16.
Lowenstein, C.J., Dinerman, J.L. and Snyder, S.H., 1994. Nitric oxide: A physiologic messenger. Annals of Internal Medicine, 120, pp. 227-237. doi:10.7326/0003-4819 120-3-199402010-00009

Nair, S.P., Williams, R.J. and Henderson, B., 2000. Advances in our understanding of the bone and joint pathology caused by Staphylococcus aureus infection. Rheumatology (Oxford) 39, pp. 821-834.

Pan, D., Jia Liu, Xiaoqun, Zeng Lu, Liu Hua, Li. and Yuxing Guo., 2015. Immunomodulatory activity of selenium exopolysaccharide produced by Lactococcus lactis subsp. Lactis. Food and Agricultural Immunology, 26 (2), pp. 248-259, http://dx.doi. org /10.1080/095401 05.2014.89400

Safir, N., Wendel, A., Saile, R. and Chabraoui, L., 2003. The effect of selenium on immune functions of J774.1 cells. Selenium and Staphylococcus aureus Eradication by Macrophage PLOS. Clinical Chemistry Laboratory Medicine, 41, pp. 1005-1011. PMID: 12964805

Savadogo, A.C.A.T., Ouattara1, Savadogo, P.W., Barro, N., Ouattara, A.S. and Traoré, A.S., 2004. Identification of exopolysaccharides-producing lactic acid bacteria from Burkina Faso fermented milk samples. African Journal of Biotechnology, 3, pp.189-194.

Savadogo, A., Ouattara, C.A., Bassole, I.H.N. and Traore, S.A. 2006. Bacteriocins and lactic acid bacteria a mini review. African Journal Biotechnology, 5(9), pp. 678 -683 .

Schumacher, K. and Roy, M., 1987. Selenium and immune function. US National Library of Medicine National Institute of Health. 42(2), pp. 277-303.

Song, J. Y., Han, S. K., Son, E. H., Pyo, S. K., Yun, Y. S. and $\mathrm{Yi}, \mathrm{S}$. Y. 2002. Induction of secretory and tumoricidal activities in peritoneal macrophages by ginsan. International Immunopharmacology, 2, pp. 857-865. doi:10.1016/S1567-5769(01)00211-9 [Crossref], [PubMed], [Web of Science $\left.{ }^{\circledR}\right]$, [Google Scholar]

Tang Y., W. Dong, K. Wan, L. Zhang, Chun Li, Lili Zhang, and Ning Liu. 2015. Exopolysaccharide Produced by Lactobacillus Plantarum Induces Maturation of Dendritic Cells in BALB/c Mice. PLOS ONE DOI:10.1371/journal.pone.0143743 November 24, 2015

Thomson, C.D., 2004. Assessment of requirements for selenium and adequacy of selenium status: a review. Dunedin: Departement of Human Nutrition University of Otago. p. 4

Thurlow, L.R., Hanke, M.L., Fritz, T., Angle, A., Aldrich, A. Williams, S.H, et al., 2011. Staphylococcus aureus biofilms prevent macrophage phagocytosis and attenuate inflammation in vivo. Journal of Immunology, 186, pp. 6585-6596. doi: 10.4049/ jimmunol.1002794 PMID: 21525381

Thwaites, G.E. and Gant, V., 2011. Are bloodstream leukocytes Trojan Horses for the metastasis of Staphylococcus aureus. Nature Reviews Microbiology, pp. 215-222.

Wahyudi, P. dan Priyanto., 2010. Uji aktivitas imunomodulator polisakarida jamur tiram putih (Pleurotus ostreatus) dan jamur shitake (Lentinus edodes) berdasar aktivitas dan kapasitas fagositosis sel makrofag peritoneum mencit secara in vivo. Farmasi Sains, 1 (1), pp. 7-13.

Wang, Ji, Zhao, X., Yang, Y., Zhao, A. and Yang, Z., 2015. Characterization and bioactivities of an exopo-lysaccharide produced by Lactobacillus plantarum. International Journal of Biological Macromolecules, 74, 119-126. 
Berita Biologi 19(3B) - Desember 2020 


\section{Pedoman Penulisan Naskah Berita Biologi}

Berita Biologi adalah jurnal yang menerbitkan artikel kemajuan penelitian di bidang biologi dan ilmu-ilmu terkait di Indonesia. Berita Biologi memuat karya tulis ilmiah asli berupa makalah hasil penelitian, komunikasi pendek dan tinjauan kembali yang belum pernah diterbitkan atau tidak sedang dikirim ke media lain. Masalah yang diliput harus menampilkan aspek atau informasi baru.

\section{Tipe naskah}

1. Makalah lengkap hasil penelitian (original paper)

Naskah merupakan hasil penelitian sendiri yang mengangkat topik yang up to date. Tidak lebih dari 15 halaman termasuk tabel dan gambar. Pencantuman lampiran seperlunya, namun redaksi berhak mengurangi atau meniadakan lampiran.

2. Komunikasi pendek (short communication)

Komuniasi pendek merupakan makalah hasil penelitian yang ingin dipublikasikan secara cepat karena hasil termuan yang menarik, spesifik dan atau baru, agar dapat segera diketahui oleh umum. Hasil dan pembahasan dapat digabung.

3. Tinjauan kembali (review)

Tinjauan kembali merupakan rangkuman tinjauan ilmiah yang sistematis-kritis secara ringkas namun mendalam terhadap topik penelitian tertentu. Hal yang ditinjau meliputi segala sesuatu yang relevan terhadap topik tinjauan yang memberikan gambaran 'state of the art', meliputi temuan awal, kemajuan hingga issue terkini, termasuk perdebatan dan kesenjangan yang ada dalam topik yang dibahas. Tinjauan ulang ini harus merangkum minimal 30 artikel.

\section{Struktur naskah}

1. Bahasa

Bahasa yang digunakan adalah Bahasa Indonesia atau Inggris yang baik dan benar.

2. Judul

Judul diberikan dalam bahasa Indonesia dan inggris. Judul ditulis dalam huruf tegak kecuali untuk nama ilmiah yang menggunakan bahasa latin, Judul harus singkat, jelas dan mencerminkan isi naskah dengan diikuti oleh nama serta alamat surat menyurat penulis dan alamat email. Nama penulis untuk korespondensi diberi tanda amplop cetak atas (superscript). Jika penulis lebih dari satu orang bagi pejabat fungsional penelitian, pengembangan agar menentukan status sebagai kontributor utama melalui penandaan simbol dan keterangan sebagai kontributor utama dicatatan kaki di halaman pertama artikel.

3. Abstrak

Abstrak dibuat dalam dua bahasa, bahasa Indonesia dan Inggris. Abstrak memuat secara singkat tentang latar belakang, tujuan, metode, hasil yang signifikan, kesimpulan dan implikasi hasil penelitian. Abstrak berisi maksimum 200 kata, spasi tunggal. Di bawah abstrak dicantumkan kata kunci yang terdiri atas maksimum enam kata, dimana kata pertama adalah yang terpenting. Abstrak dalam Bahasa Inggris merupakan terjemahan dari Bahasa Indonesia. Editor berhak untuk mengedit abstrak demi alasan kejelasan isi abstrak.

4. Pendahuluan

Pendahuluan berisi latar belakang, permasalahan dan tujuan penelitian. Perlu disebutkan juga studi terdahulu yang pernah dilakukan terkait dengan penelitian yang dilakukan.

5. Bahan dan cara kerja

Bahan dan cara kerja berisi informasi mengenai metode yang digunakan dalam penelitian. Pada bagian ini boleh dibuat sub-judul yang sesuai dengan tahapan penelitian. Metoda harus dipaparkan dengan jelas sesuai dengan standar topik penelitian dan dapat diulang oleh peneliti lain. Apabila metoda yang digunakan adalah metoda yang sudah baku cukup ditulis sitasinya dan apabila ada modifikasi maka harus dituliskan dengan jelas bagian mana dan hal apa yang dimodifikasi.

6. Hasil

Hasil memuat data ataupun informasi utama yang diperoleh berdasarkan metoda yang digunakan. Apabila ingin mengacu pada suatu tabel/ grafik/diagram atau gambar, maka hasil yang terdapat pada bagian tersebut dapat diuraikan dengan jelas dengan tidak menggunakan kalimat 'Lihat Tabel 1'. Apabila menggunakan nilai rata- rata maka harus menyertakan pula standar deviasinya.

7. Pembahasan

Pembahasan bukan merupakan pengulangan dari hasil. Pembahasan mengungkap alasan didapatkannya hasil dan arti atau makna dari hasil yang didapat tersebut. Bila memungkinkan, hasil penelitian ini dapat dibandingkan dengan studi terdahulu.

8. Kesimpulan

Kesimpulan berisi infomasi yang menyimpulkan hasil penelitian, sesuai dengan tujuan penelitian, implikasi dari hasil penelitian dan penelitian berikutnya yang bisa dilakukan.

9. Ucapan terima kasih

Bagian ini berisi ucapan terima kasih kepada suatu instansi jika penelitian ini didanai atau didukungan oleh instansi tersebut, ataupun kepada pihak yang membantu langsung penelitian atau penulisan artikel ini.

10. Daftar pustaka

Tidak diperkenankan untuk mensitasi artikel yang tidak melalui proses peer review. Apabila harus menyitir dari "laporan" atau "komunikasi personal" dituliskan 'unpublished' dan tidak perlu ditampilkan di daftar pustaka. Daftar pustaka harus berisi informasi yang up to date yang sebagian besar berasal dari original papers dan penulisan terbitan berkala ilmiah (nama jurnal) tidak disingkat.

\section{Format naskah}

1. Naskah diketik dengan menggunakan program Microsoft Word, huruf New Times Roman ukuran 12, spasi ganda kecuali Abstrak spasi tunggal. Batas kiri-kanan atas-bawah masing-masing 2,5 cm. Maksimum isi naskah 15 halaman termasuk ilustrasi dan tabel.

2. Penulisan bilangan pecahan dengan koma mengikuti bahasa yang ditulis menggunakan dua angka desimal di belakang koma. Apabila menggunakan Bahasa Indonesia, angka desimal ditulis dengan menggunakan koma (.) dan ditulis dengan menggunakan titik (.) bila menggunakan bahasa Inggris. Contoh: Panjang buku adalah 2,5 cm. Lenght of the book is $2.5 \mathrm{~cm}$. Penulisan angka $1-9$ ditulis dalam kata kecuali bila bilangan satuan ukur, sedangkan angka 10 dan seterusnya ditulis dengan angka. Contoh lima orang siswa, panjang buku $5 \mathrm{~cm}$.

3. Penulisan satuan mengikuti aturan international system of units.

4. Nama takson dan kategori taksonomi ditulis dengan merujuk kepada aturan standar yang diakui. Untuk tumbuhan menggunakan International Code of Botanical Nomenclature (ICBN), untuk hewan menggunakan International Code of Zoological Nomenclature (ICZN), untuk jamur International Code of Nomenclature for Algae, Fungi and Plant (ICFAFP), International Code of Nomenclature of Bacteria (ICNB), dan untuk organisme yang lain merujuk pada kesepakatan Internasional. Penulisan nama takson lengkap dengan nama author hanya dilakukan pada bagian deskripsi takson, misalnya pada naskah taksonomi. Penulisan nama takson untuk bidang lainnya tidak perlu menggunakan nama author.

5. Tata nama di bidang genetika dan kimia merujuk kepada aturan baku terbaru yang berlaku.

6. Untuk range angka menggunakan en dash (-), contohnya pp.1565-1569, jumlah anakan berkisar 7-8 ekor. Untuk penggabungan kata menggunakan hyphen (-), contohnya: masing-masing.

7. Ilustrasi dapat berupa foto (hitam putih atau berwarna) atau gambar tangan (line drawing).

8. Tabel

Tabel diberi judul yang singkat dan jelas, spasi tunggal dalam bahasa Indonesia dan Inggris, sehingga Tabel dapat berdiri sendiri. Tabel diberi nomor urut sesuai dengan keterangan dalam teks. Keterangan Tabel diletakkan di bawah Tabel. Tabel tidak dibuat tertutup dengan garis vertikal, hanya menggunakan garis horisontal yang memisahkan judul dan batas bawah. 
8. Gambar

Gambar bisa berupa foto, grafik, diagram dan peta. Judul gambar ditulis secara singkat dan jelas, spasi tunggal. Keterangan yang menyertai gambar harus dapat berdiri sendiri, ditulis dalam bahasa Indonesia dan Inggris. Gambar dikirim dalam bentuk .jpeg dengan resolusi minimal 300 dpi, untuk line drawing minimal 600dpi.

9. Daftar Pustaka

Sitasi dalam naskah adalah nama penulis dan tahun. Bila penulis lebih dari satu menggunakan kata 'dan' atau et al. Contoh: (Kramer, 1983), (Hamzah dan Yusuf, 1995), (Premachandra et al., 1992). Bila naskah ditulis dalam bahasa Inggris yang menggunakan sitasi 2 orang penulis maka digunakan kata 'and'. Contoh: (Hamzah and Yusuf, 1995). Jika sitasi beruntun maka dimulai dari tahun yang paling tua, jika tahun sama maka dari nama penulis sesuai urutan abjad. Contoh: (Anderson, 2000; Agusta et al., 2005; Danar, 2005). Penulisan daftar pustaka, sebagai berikut:

a. Jurnal

Nama jurnal ditulis lengkap.

Agusta, A., Maehara, S., Ohashi, K., Simanjuntak, P. and Shibuya, H., 2005. Stereoselective oxidation at C-4 of flavans by the endophytic fungus Diaporthe sp. isolated from a tea plant. Chemical and Pharmaceutical Bulletin, 53(12), pp.1565-1569.

b. Buku

Anderson, R.C. 2000. Nematode Parasites of Vertebrates, Their Development and Tramsmission. 2nd ed. CABI Publishing. New York. pp. 650 .

c. Prosiding atau hasil Simposium/Seminar/Lokakarya.

Kurata, H., El-Samad, H., Yi, T.M., Khammash, M. and Doyle, J., 2001. Feedback Regulation of the Heat Shock Response in Eschericia coli. Proceedings of the 40th IEEE Conference on Decision and Control. Orlando, USA. pp. 837-842.

d. Makalah sebagai bagian dari buku

Sausan, D., 2014. Keanekaragaman Jamur di Hutan Kabungolor, Tau Lumbis Kabupaten Nunukan, Kalimanan Utara. Dalam: Irham, M. \& Dewi, K. eds. Keanekaraman Hayati di Beranda Negeri. pp. 47-58. PT. Eaststar Adhi Citra. Jakarta.

e. Thesis, skripsi dan disertasi

Sundari, S., 2012. Soil Respiration and Dissolved Organic Carbon Efflux in Tropical Peatlands. Dissertation. Graduate School of Agriculture. Hokkaido University. Sapporo. Japan.

f. Artikel online.

Artikel yang diunduh secara online ditulis dengan mengikuti format yang berlaku untuk jurnal, buku ataupun thesis dengan dilengkapi alamat situs dan waktu mengunduh. Tidak diperkenankan untuk mensitasi artikel yang tidak melalui proses peer review misalnya laporan perjalanan maupun artikel dari laman web yang tidak bisa dipertangung jawabkan kebenarannya seperti wikipedia.

Himman, L.M., 2002. A Moral Change: Business Ethics After Enron. San Diego University Publication. http:ethics.sandiego.edu/LMH/ oped/Enron/index.asp. (accessed 27 Januari 2008) bila naskah ditulis dalam bahasa inggris atau (diakses 27 Januari 2008) bila naskah ditulis dalam bahasa indonesia

Formulir persetujuan hak alih terbit dan keaslian naskah

Setiap penulis yang mengajukan naskahnya ke redaksi Berita Biologi akan diminta untuk menandatangani lembar persetujuan yang berisi hak alih terbit naskah termasuk hak untuk memperbanyak artikel dalam berbagai bentuk kepada penerbit Berita Biologi. Sedangkan penulis tetap berhak untuk menyebarkan edisi cetak dan elektronik untuk kepentingan penelitian dan pendidikan. Formulir itu juga berisi pernyataan keaslian naskah yang menyebutkan bahwa naskah adalah hasil penelitian asli, belum pernah dan tidak sedang diterbitkan di tempat lain serta bebas dari konflik kepentingan.

\section{Penelitian yang melibatkan hewan dan manusia}

Setiap naskah yang penelitiannya melibatkan hewan (terutama mamalia) dan manusia sebagai obyek percobaan/penelitian, wajib menyertakan 'ethical clearance approval' yang dikeluarkan oleh badan atau pihak berwenang.

\section{Lembar ilustrasi sampul}

Gambar ilustrasi yang terdapat di sampul jurnal Berita Biologi berasal dari salah satu naskah yang dipublikasi pada edisi tersebut. Oleh karena itu, setiap naskah yang ada ilustrasinya diharapkan dapat mengirimkan ilustrasi atau foto dengan kualitas gambar yang baik dengan disertai keterangan singkat ilustrasi atau foto dan nama pembuat ilustrasi atau pembuat foto.

\section{Proofs}

Naskah proofs akan dikirim ke penulis dan penulis diwajibkan untuk membaca dan memeriksa kembali isi naskah dengan teliti. Naskah proofs harus dikirim kembali ke redaksi dalam waktu tiga hari kerja.

\section{Pengiriman naskah}

Naskah dikirim secara online ke website berita biologi: http://e-journal.biologi.lipi.go.id/index.php/berita_biologi

\section{Alamat kontak}

Redaksi Jurnal Berita Biologi, Pusat Penelitian Biologi-LIPI

Cibinong Science Centre, Jl. Raya Bogor Km. 46 Cibinong 16911

Telp: +61-21-8765067, Fax: +62-21-87907612, 8765063,8765066,

Email: berita.biologi@mail.lipi.go.id

jurnalberitabiologi@yahoo.co.id atau

jurnalberitabiologi@gmail.com 


\section{BERITA BIOLOGI}

Vol. 19(3B)

Isi (Content)

Desember 2020

P-ISSN 0126-1754

E-ISSN 2337-8751

TINJAUAN ULANG (REVIEW)

TEKNOLOGI PIRAMIDA GEN TANAMAN PADI DALAM MENGHADAPI PERUBAHAN IKLIM GLOBAL

[Pyramiding Gene Technology in Rice to Anticipate the Impact of Global Climate Change]

Fatimah, Joko Prasetiyono, dan Sustiprijatno

MEKANISME RESPON TANAMAN TERHADAP CEKAMAN KEKERINGAN

[The Mechanism of Plant Response to Drought Stress]

Dwi Setyo Rini, Budiarjo, Indra Gunawan, Radi Hidayat Agung, dan Rina Munazar

\section{MAKALAH HASIL RISET (ORIGINAL PAPERS)}

PERILAKU SINYAL AKUSTIK DAN VISUAL DARI KATAK JANTAN Staurois gutattus DI GUNUNG POTENG KALIMANTAN BARAT

[Behavior of Acoustic and Visual Signals From the Male Frog Staurois gutattus at Mountain Poteng West

Kalimantan]

Mohamad Jakaria, Junardi, dan Riyandi

MONITORING KEANEKARAGAMAN JENIS BURUNG PADA BERBAGAI TUTUPAN LAHAN DI CIBINONG SCIENCE CENTER (CSC), JAWA BARAT

[Monitoring of Bird Diversity in Various Land Cover in Cibinong Science Center (CSC), West Java]

Yohanna.....

Efektivitas Dosis Karbon Tetraklorida $\left(\mathrm{CCl}_{4}\right)$ Terhadap Tikus (Rattus norvegicus $\mathbf{L}$.) Sebagai Hewan Model

Fibrosis Hati

[The Effectiveness Of Carbon Tetracloride $\left(\mathrm{CCl}_{4}\right)$ Dosage On Rats As Animal Model Liver Fibrosis]

Fahri Fahrudin, Sri Ningsih, Hajar Indra Wardhana, Dinda Rama Haribowo, dan Fathin Hamida

LARVA TREMATODA PADA SIPUT AIR TAWAR DI AREAL PERSAWAHAN DAERAH ISTIMEWA

YOGYAKARTA

[Trematode Larvae in Freshwater Snail on Rice Fields Area in Special Region of Yogyakarta]

Soenarwan Hery Poerwanto, Dian Antika Kusuma Dewi, dan Giyantolin

THE FUNCTIONAL CHARACTER OF Auricularia auricula CRUDE POLYSACCHARIDES: ANTIOXIDANT AND ANTIBACTERIAL ACTIVITY

[Karakter Fungsional dari Ekstrak Kasar Polisakarida Auricularia auricula: Aktivitas Antioksidan dan

Antibakteri]

Rizki Rabeca Elfirta dan Iwan Saskiawan

ISOLASI DAN KARAKTERISASI ISOLAT BAKTERI RESISTEN TEMBAGA DARI SUNGAI CISADANE

[Isolation and Characterization of Copper Resistant Bacteria from Cisadane River]

Wahyu Irawati dan Candra Yulius Tahya

ANALISIS KERAGAMAN GENETIK AKSESI KEDELAI INTRODUKSI DARI WILAYAH SUBTROPIS BERBASIS MORFOLOGI DAN MOLEKULER

[Morphologicaland Molecular Based Genetic Diversity Assessment Among Soybean Accessions Introduced from Subtropical Areas]

Rerenstradika Tizar Terryana, Nickita Dewi Safina, Suryani, Kristianto Nugroho, dan Puji Lestari

EFEK SELENIUM OKSIKLORIDA TERHADAP AKTIVITAS IMUNOMODULATOR DARI EKSOPOLI-

SAKARIDA Lactobacillus plantarum

[Effect of Selenium Chloride on Immunomodulatory Activity of Exopolysaccharide by Lactobacillus

plantarum]

Fifi Afiati, D.C. Agustina, S. Wiryowidagdo, Kusmiati, dan Atit Kanti

FLUKTUASI KEPADATAN MEGABENTOS DI PERAIRAN KENDARI, SULAWESI TENGGARA

[Density Fluctuation of Megabenthic Fauna in Kendari Waters, South-East Sulawesi]

Ucu Yanu Arbi, Paiga Hanurin Sawonua, dan Hendrik A.W. Cappenberg 